\title{
Lysis-induced decline of a Phaeocystis spring bloom and coupling with the microbial foodweb
}

\author{
W. H. M. van Boekel ${ }^{1,2}$, F. C. Hansen ${ }^{2}$, R. Riegman' ${ }^{2}$, R. P. M. Bak \\ 'Department of Marine Biology, University of Groningen, PO Box 14, 9750 AA Haren, The Netherlands \\ ${ }^{2}$ Netherlands Institute for Sea Research, PO Box 59, $1790 \mathrm{AB}$ Den Burg, The Netherlands
}

\begin{abstract}
We studied the development and decline of the 1990 phytoplankton spring bloom in the Marsdiep area of the North Sea (The Netherlands) with emphasis on the cause of the decline of the Phacocystis bloom, the role of microbial organisms and the utilization of organic material produced by the algae. At the top of the bloom Phaeocystis was nitrogen limited. The bloom declined through cell lysis. Sinking of colonies and grazing were found to be relatively unimportant as loss factors. Biomass in the microbial foodweb (bacteria and protozooplankton) remained low during the bloom but increased sharply as the bloom started to decline indicating that organic carbon released by the phytoplankton was rapidly utilized in the microbial foodweb. Results suggest that dissolved organic carbon produced by phytoplankton through excretion and lysis was the main source of carbon for the microbial foodweb including copepods
\end{abstract}

\section{INTRODUCTION}

The spring development of phytoplankton in the Southern Bight of the North Sea is characterized by a diatom bloom, closely followed by a bloom of the colony-forming Prymnesiophycean Phaeocystis sp. (Lancelot et al. 1987). This spring bloom has been studied most thoroughly in the Marsdiep area near the Island of Texel, The Netherlands (Cadée \& Hegeman 1986, 1991). Over the last 2 decades Phaeocystis has shown an increase in duration of the bloom and in maximum cell number reached during the bloom in this area. There is evidence that this trend is related to an increase of riverine nutrient input in the area (Cadée \& Hegeman 1986, Lancelot et al. 1987).

Phaeocystis is usually the only non-diatom alga that takes advantage of the nutrients left after the diatom bloom. The success of this species in competing with other non-diatoms can be explained by its poor availability as a food source for herbivores. Colonies reach sizes of $2 \mathrm{~mm}$ in diameter and are mostly too large for predation by copepods and other zooplankton. Bivalves also prey inefficiently on Phaeocystis colonies (Beukema \& Cadée 1991). Single cells of Phaeocystis are 3 to $8 \mu \mathrm{m}$ in diameter and therefore at the lower limit of the food-size range found for copepods (Verity
\& Smayda 1989, Estep et al. 1990j. Even though some authors report predation on Phaeocystis single cells and colonies by copepods or ciliates (Weisse 1983, Admiraal \& Venekamp 1986, Hansen et al. 1990, Weisse \& Scheffel-Möser 1990), it is not yet clear if this predation has much quantitative significance. Hansen \& van Boekel (1991) found that copepod grazing on phytoplankton during the 1990 Phaeocystis spring bloom in the Marsdiep removed less than $1 \%$ of the phytoplankton standing stock per day.

Since grazing is probably not important as a loss factor during the Phaeocystis bloom, questions arise as to what causes the bloom to decline and what happens to the carbon fixed during the bloom. Sinking was an important loss factor during a Phaeocystis bloom in the Barents Sea (Wassmann et al. 1990). Also lysis of algal cells occurring at the end of the bloom, when nitrogen or phosphate limit further biomass increase, could result in decreasing cell densities. Riegman et al. (1990) showed that nutrient limitation occurred during a Phaeocystis bloom in the Marsdiep. Their results were not specific for Phaeocystis since the total phytoplankton community was studied. More than 1 nutrient was found to be limiting on several occasions during the bloom. It remained to be shown therefore, if, and by which nutrient, Phaeocystis growth was limited. The 
aim of the present study was to determine what causes the breakdown of the Phaeocystis bloom in the Marsdiep and what happens with the Phaeocystis biomass. During the 1990 spring bloom we followed the development of phytoplankton and microbial organisms as well as parameters for nutrient limitation, phytoplankton cell lysis, and sinking of Phaeocystis colonies.

\section{METHODS}

Sampling procedure. Samples were collected at a jetty in the Marsdiep south of the Island of Texel, The Netherlands, between 21 March 1990 (Day 80) and 11 May 1990 (Day 131). All samples were collected at high water during the day. Sampling was most frequent during the Phaeocystis bloom period. Samples were taken to the laboratories and processed immediately.

Chemical analysis. Concentrations of silicate, inorganic phosphate (Pi), dissolved organic phosphate (DOP), ammonium, nitrite and nitrate were determined in water filtered through pre-rinsed $0.2 \mu \mathrm{m}$ celluloseacetate filters. Silicate and inorganic nitrogen compounds were determined according to Strickland $\&$ Parsons (1972) with an auto-analyzer and Pi according to Murphy \& Riley (1962). DOP was determined as inorganic phosphate after persulfate oxidation $\left(2 \mathrm{~h}, 120^{\circ} \mathrm{C}\right)$ of filtered samples. This method was also used for determination of total phosphorus concentration in the Phaeocystis fraction (see below).

Phytoplankton. Cell numbers and species composition of phytoplankton were determined with the Utermöhl sedimentation technique (Utermöhl 1958) in samples fixed with buffered Lugol solution. Samples for chl a analysis were collected by filtering 0.5 to $1 \mathrm{l}$ seawater over a GF/F Whatman filter. Filters were stored at $-20^{\circ} \mathrm{C}$ until analysis. Chlorophyll $a$ and phaeopigment concentration were measured spectrophotometrically (Lorenzen 1967).

Phaeocystis colonies. During the Phaeocystis bloom period (Days 92 to 114) colonies of Phaeocystis were separated from the other phytoplankton by filtration through a $300 \mu \mathrm{m}$ mesh-size netting. This retained most colonies while other phytoplankton passed through. Colonies were resuspended in filtered seawater. Density of colonies in this resuspended sample (Phaeocystis-fraction) was in the same range as in the untreated field sample. Colonies showed no visual damage after treatment. The Phaeocystis-fraction was used to determine the $\mathrm{P}$ content and the maximum phosphate uptake rate $\left(V_{\text {mox, }}\right.$ ) of Phaeocystis colony cells and the sinking rate of the colonies.

Phosphorus content of Phaeocystis. Phaeocystis P content was calculated by subtracting the dissolved
P fraction ( $\mathrm{Pi}+\mathrm{DOP})$ from the total phosphorus content of the Phaeocystis fraction.

Maximum Pi uptake rate of Phaeocystis. The $V_{\max , \mathrm{Pi}}$ of Phaeocystis cells was determined according to Riegman et al. (1990). This parameter can be regarded as an indicator for phosphate limitation, since P-limited cells show strongly increased $V_{\text {tia } x, P_{1}}$ values compared with P-sufficient cells (Zevenboom et al. 1982). For P-sufficient Phaeocystis colony cells a $V_{\text {max }}$ Pi value of

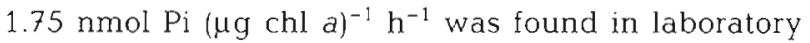
experiments (van Boekel unpubl.). This value was used to distinguish between P-limited and P-sufficient colony cells during the Phaeocystis bloom.

Sinking rate of Phaeocystis. The sinking rate of Phaeocystis colonies was determined with the SETCOL method developed by Bienfang (1981). This method does not yield in situ sinking rates, but sinking rates of colonies at different stages of the Phaeocystis bloom can be compared since the experimental conditions $\left(15^{\circ} \mathrm{C}\right.$, dim light) were kept constant for all measurements.

Phytoplankton autolysis. Estimation of phytoplankton autolysis rates was based on the presence of esterase activity (EA) in the dissolved fraction of water samples. This parameter was chosen since esterases are strictly cytoplasmatic enzymes (Dixon \& Webb 1979) and thus are expected to appear in the water only after cell breakage. In algal batch cultures a strong (up to 10-fold) increase of EA had been observed at the end of the exponential growth phase. This increase coincided with microscopically observed cytoplasm release by cells. Laboratory experiments also showed that grazing of phytoplankton by a calanoid copepod or the heterotrophic dinoflagellate Oxyrrhis marina did not stimulate EA release. Addition of bacteria $\left(10^{6} \mathrm{ml}^{-1}\right)$ to algal cultures caused an increase of EA of less than $5 \%$ (Riegman unpubl.). These preliminary experiments showed that EA is a sufficiently adequate parameter for the measurement of algal cell lysis.

Dissolved EA in field samples was measured by adding $30 \mu \mathrm{l}$ fluorescein-diacetate (FDA, 2mM in $100 \%$ acetone) and $30 \mu \mathrm{l} 20 \mathrm{Mm}$ EDTA $(\mathrm{pH}=8.0)$ to a $3 \mathrm{ml}$ sample which had been gently filtered through a $0.2 \mu \mathrm{m}$ filter. EDTA was added for stabilization of FDA in sea water Samples were incubated at $20^{\circ} \mathrm{C}$ for $1 \mathrm{~h}$, after which sample fluorescence was measured on a Hitachi F2000 fluorometer (excitation at $451 \mathrm{~nm}$, emission at $510 \mathrm{~nm}$ with $10 \mathrm{~nm}$ bandwidth). Simultaneously, the stability of dissolved EA was tested by adding sonicated Isochrysis sp. culture samples to field samples and measuring EA for $24 \mathrm{~h}$ at field temperature. The addition of extra Isochrysis sp. EA was done in order to be able to follow EA breakdown more accurately. Within the temperature-and protease activity range $\left(8\right.$ to $14^{\circ} \mathrm{C}$ and 0.2 to $3 \mu \mathrm{mol}$ naphthyl min ${ }^{-1}$, 
respectively) found during the sampling period, the degradation rate of the added EA was found to be constant at $25 \pm 5 \% \mathrm{~d}^{-1}$. From the net change of $E A$ in field samples and a daily degradation rate of $25 \%$, EA released over time was calculated. Released EA was related to particulate EA present in the phytoplankton yielding the specific daily phytoplankton autolysis rate (expressed as \% particulate EA released $\mathrm{d}^{-1}$ ).

Phytoplankton particulate EA could not be measured directly in field samples due to interference by particulate EA from other planktonic organisms (bacteria, zooplankters). Therefore, particulate phytoplankton EA was estimated from the chl a concentration in the field samples and an EA/chl a ratio, derived from exponentially growing algae in batch cultures. The $\mathrm{EA} / \mathrm{chl}$ a ratio for Thalassiosira $\mathrm{sp}$, Rhodomonas $\mathrm{sp}$., Chaetoceros socialis, Stephanopyxis $\mathrm{sp}$., Isochrysis sp. Emiliania huxleyi, Lauderia borealis, Phaeocystis sp. and Ditylum brightwellii was 5.5, 6.8, 19.1, 17.6, 21.6, $9.2,9.0,15.0$ and $9.2 \mathrm{nmol}$ fluorescein $(\mu \mathrm{g} \mathrm{chl} a)^{-1} \mathrm{~h}^{-1}$, respectively. For estimation of particulate phytoplankton $\mathrm{EA}$ in field samples the mean of these values [12.6

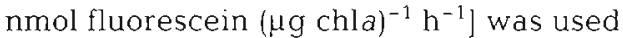

Bacterioplankton. Bacteria were counted and measured with epifluorescence microscopy (Hobbie et al 1977). For procedures see van Duyl et al. (1990). To

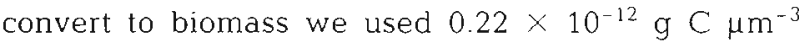
biovolume (Bratbak \& Dundas 1984).

Protozooplankton. Nanoflagellates, virtually representing all protists $<20 \mu \mathrm{m}$, were fixed with glutaraldehyde ( $1 \%$ final concentration), stained with proflavine and $4 \mathrm{ml}$ subsamples were gently filtered over $0.2 \mu \mathrm{m}$ filters (for exact procedures see van Duyl et al. 1990, Bak \& Nieuwland 1991). Flagellates were counted and measured with epifluorescence microscopy. Phototrophic nanoflagellates were distinguished through the presence of autofluorescence of chlorophyll. Conversion to biomass was based on a factor of

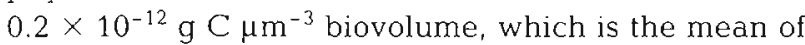
values determined by Fenchel (1982) and Børsheim \& Bratbak (1987). To obtain densities of ciliates subsamples of $20 \mathrm{ml}$ were fixed with acid Lugol solution. Ciliates were counted and measured between 2 and $24 \mathrm{~h}$ after collection using Utermöhl's sedimentation technique. The conversion factor to biomass was $0.19 \times$

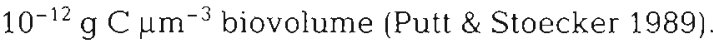

Copepods. Sampling and determination procedures for copepods have been described by Hansen \& van Boekel (1991). Copepod biomass was calculated using data from this paper and unpublished results. Since only Temora longicornis biomass was determined, total copepod biomass was calculated from data on copepod numbers and the Temora mean specific biomass. Thus, an equal mean specific weight for all copepod species was assumed. Temora presented
$80 \%$ or more of total copepod number in most samples, so only a small deviation from real biomass values should be expected using this assumption.

\section{RESULTS}

\section{Nutrients}

As sampling started (Day 80) all nutrients were still present in high concentrations (Fig. 1). At Day 92 silicate concentration had dropped to $1.5 \mu \mathrm{mol} \mathrm{l}^{-1}$ and remained low thereafter. Pi concentration decreased to $0.25 \mu \mathrm{mol} \mathrm{I}^{-1}$ on Day 99. Concentration of nitrogenous nutrients (mostly nitrate) reached lowest levels on Day $105\left(1.81 \mu \mathrm{mol} \mathrm{l}^{-1}\right.$ total dissolved inorganic nitrogen). Both Pi and nitrate concentration slowly increased again after Day 109. Ammonium was undetectable from Day 85 until Day 114, but was found again at relatively high concentration $\left(3.7 \mu \mathrm{mol} \mathrm{l}^{-1}\right)$ on Days 117 and 121. DOP concentration was constant at ca $0.2 \mu \mathrm{mol} \mathrm{l}^{-1}$ during the sampling period (not shown).

\section{Phytoplankton}

Diatom cell number showed an initial peak on Day 92 (Fig. 2a); large species (Biddulphia sinensis, Thalassiosira sp.) dominated the population. Thereafter, diatom cell number fluctuated strongly, reflecting a succession of smaller species dominating the population. Phaeocystis cell number started to increase from Day 92, reaching highest levels on Day $105\left(67.7 \times 10^{6} \mathrm{l}^{-1}\right)$ (Fig. 2a). At that moment Phaeocystis comprised more than $80 \%$ of total phytoplankton biovolume (Hansen \& van Boekel 1991). The Phaeocystis population then declined sharply. A second peak, consisting of Phaeocystis microflagellates together with the diatom Asterionella glacialis, was found on Day 114 . The chl a concentration in the water reflected the 3 peaks (diatoms, Phaeocystis colonies and -microflagellates) in cell numbers (Fig. 2b). Phytoplankton cell lysis rate is given in Fig. 2c. Two peaks of high lysis rates were found on Days 108 and 120 following the peaks of Phaeocystis colonies and -microflagellates, respectively.

\section{Phaeocystis colony fraction}

The P content of Phaeocystis colony cells remained at a rather constant level of $0.045 \pm 0.017 \mathrm{pmol} \mathrm{cell}^{-1}$ during the bloom period (not shown). The lowest value $\left(0.0245\right.$ pmol cell $\left.{ }^{-1}\right)$ was found on Day 114 . The maximum uptake rate for phosphate of Phaeocystis colony cells did not reach high values during the Phaeocystis 

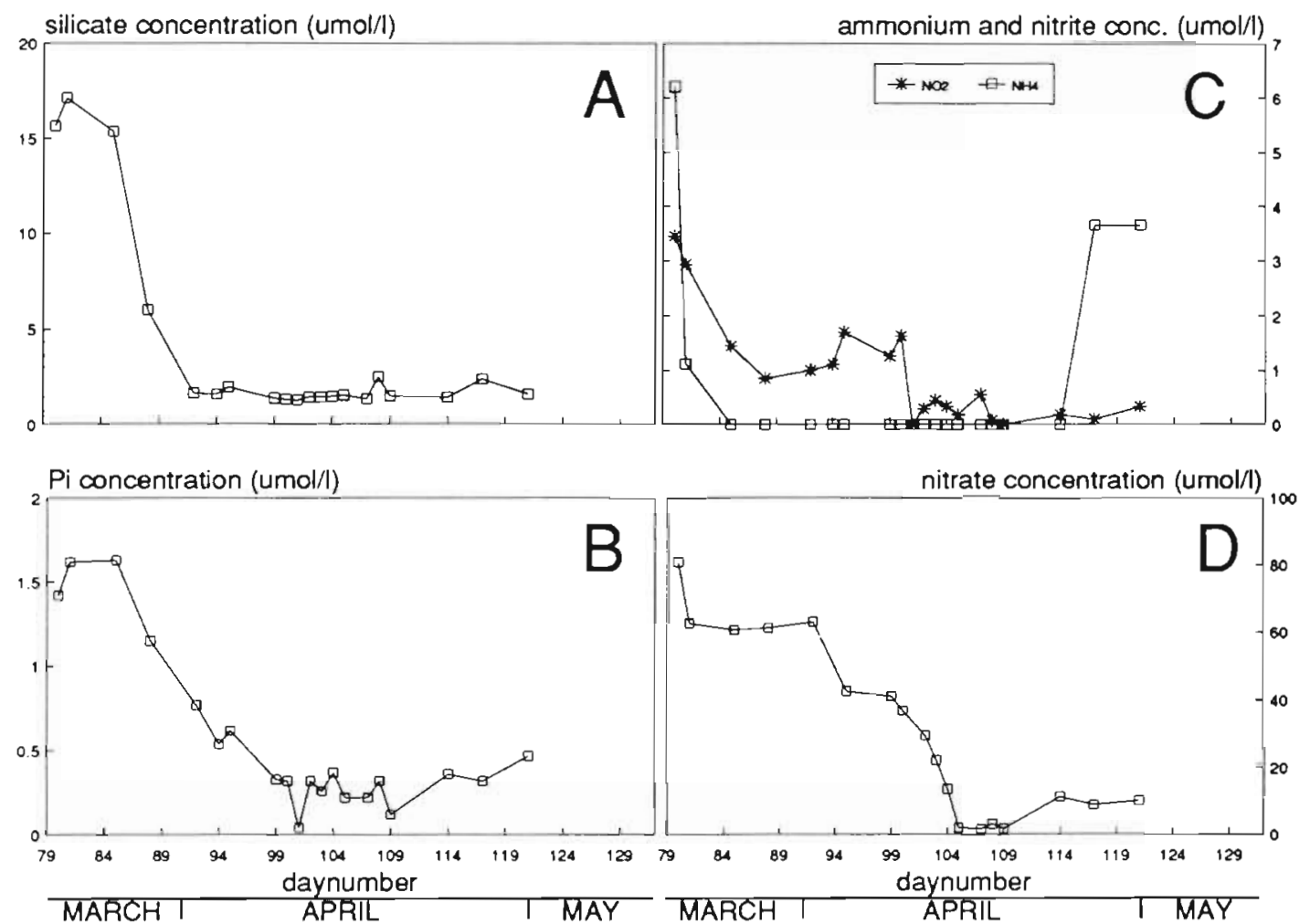

Fig. 1 Time course of the concentration of (A) silicate, (B) inorganic phosphate (Pi), (C) ammonium and nitrite, and (D) nitrate in the Marsdiep water during spring 1990

bloom (Fig. 3). At the top of the bloom (around Day 105), $V_{\max }$ p values were indeed far below the threshold value for Pi limitation. High values were only found on Day 88 and 114, outside the Phaeocystis bloom period. Sinking rate measurements, made at regular intervals during the Phaeocystis bloom period, showed that the sinking rate of the colonies remained rather constant at $0.25 \pm 0.08 \mathrm{~m} \mathrm{~h}^{-1}(\mathrm{n}=16)$ (Fig. 4). The lowest sinking rate was found at the maximum of the bloom. There was no clear relation between sinking rate and stage of the Phaeocystis bloom development.

\section{Bacterioplankton}

Bacterioplankton increased relatively slowly during the phytoplankton bloom period (Fig 5a). A rapid increase occurred between Day 107 and 110 during the breakdown of the Phaeocystis bloom. After Day 114 bacterial biomass declined.

\section{Protozooplankton}

Nanoflagellate biomass showed the same development as bacterial biomass (Fig. 5b). Ciliate biomass also increased most rapidly after the Phaeocystis bloom period (Fig. 5c) reaching highest levels a few days after bacteria and nanoflagellates. In contrast with bacteria and nanoflagellates the biomass of ciliates remained high for a period of ca $10 \mathrm{~d}$ (Day 110 to 121).

\section{Copepods}

Generally, copepod biomass developed steadily from Day 99 on, with 2 peaks at Days 110 and 121 (Fig. 5d). Temora longicornis comprised $>90 \%$ of total copepod number until Day 121 (Hansen \& van Boekel 1991).

\section{DISCUSSION}

\section{Fate of Phaeocystis}

Data suggest that limitation of the Phaeocystis spring bloom of 1990 in the Marsdiep area was caused by depletion of inorganic nitrogen in the water. This resulted in cell lysis (Figs. 1d, 2a \& c). Nitrogen limitation of Phaeocystis was not shown directly, but substantial support for this statement is found in the results.

Firstly, sinking and grazing were relatively unimportant as loss factors. Sinking rates of Phaeocystis colonies did not change dramatically during the bloom 

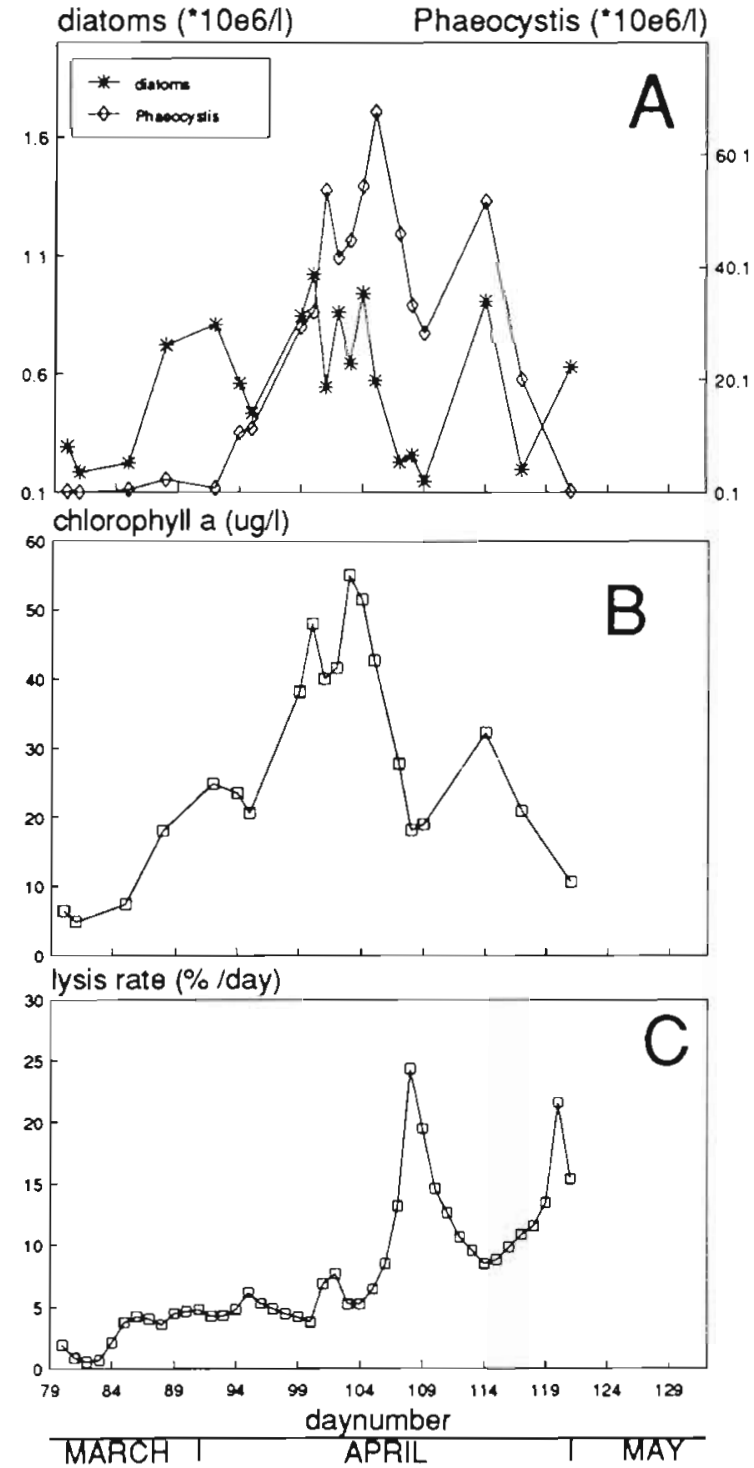

Fig. 2. Time course of (A) cell numbers of diatoms and Phaeocystis, (B) chlorophyll a concentration, and (C) lysis rate of phytoplankton in the Marsdiep water during spring 1990

period (Fig. 4), indicating that increased loss of colonies through sinking during the decline of the bloom is not likely. Also, in the turbulent Marsdiep water loss through sinking would have been minimal. In general, net sedimentation is relatively unimportant in Dutch coastal waters since high current velocities cause resuspension of deposited material (Jennes \& Duineveld 1985). It has been postulated by Creutzberg et al. (1984) that phytoplankton biomass that is not consumed in the pelagic system is transported to less turbulent zones like the Frisian front where it ultimately settles. Grazing on Phaeocystis by copepods was shown to be insignificant by Hansen \& van Boekel (1991). Ciliates, which can graze Phaeocystis single

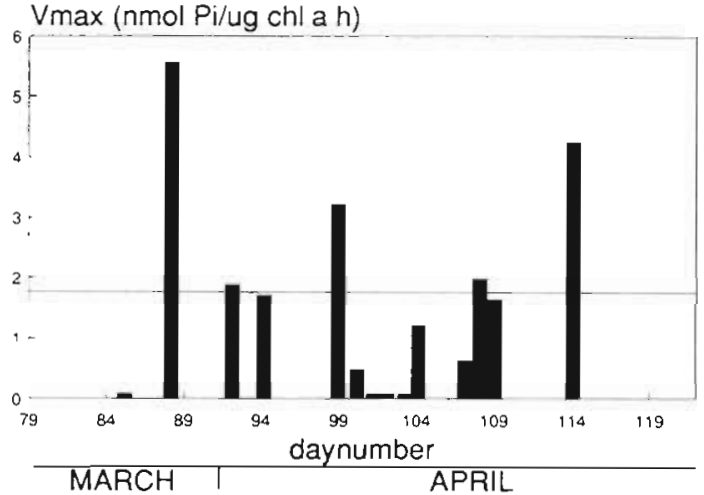

Fig. 3. Maximum uptake rate of inorganic phosphate $\left(V_{\max , \mathrm{P}_{i}}\right)$ by Phaeocystis cells in the Phaeocystis fraction collected from the Marsdiep, spring 1990 . Horizontal line indicates the $V_{\max . P_{1}}$ value of P-sufficient Phaeocystis cells $[=1.75 \mathrm{pmol} \mathrm{Pi}$ $(\mu \mathrm{gchl} a)^{-1} \mathrm{~h}^{-1}$ ]

cells (Admiraal \& Venekamp 1986, Weisse \& ScheffelMöser 1990), remained low in biomass during the bloom period (Fig. 5c).

Lysis of phytoplankton cells showed a peak just after the top of the Phaeocystis bloom (Fig. 2). This suggests that the decline of the bloom was caused by cell death, most probably as a consequence of nutrient limitation The 2 major nutrients for Phaeocystis are nitrogen and phosphate. Inorganic nitrogen in the water was depleted at the top of the Phaeocystis bloom while inorganic phosphate remained at relatively high concentrations (Fig. 1). Also, the P content of Phaeocystis cells $\left(0.045 \mathrm{pmol}\right.$ cell $\left.^{-1}\right)$ was high compared with values found for P-limited cells $\left(0.01 \mathrm{pmol} \mathrm{cell}^{-1}\right.$; van Boekel \& Veldhuis 1990). The low $V_{\max , \mathrm{Pi}}$ values at the top of the bloom indicated that Phaeocystis was not P-limited (Fig. 3). Therefore, it is reasonable to state that nitrogen limitation caused the lysis of Phaeocystis cells. Nitrate limitation of phytoplankton was also

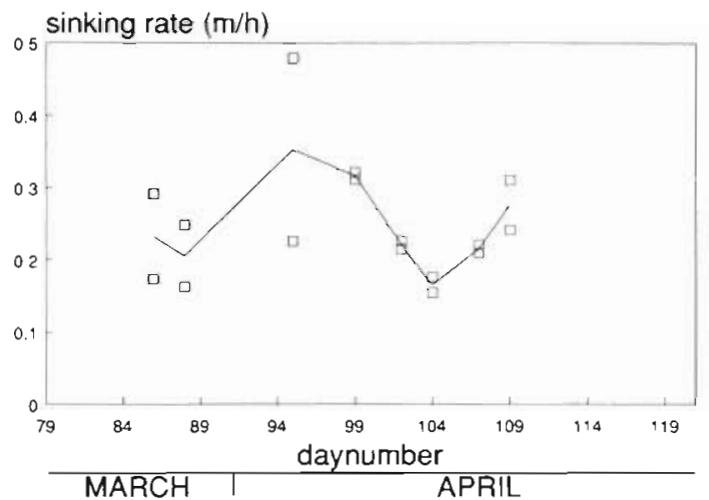

Fig. 4. Sinking rate of Phaeocystis colonies in the Phaeocystis fraction, determined with the SETCOL method. Line connects means of duplicates 

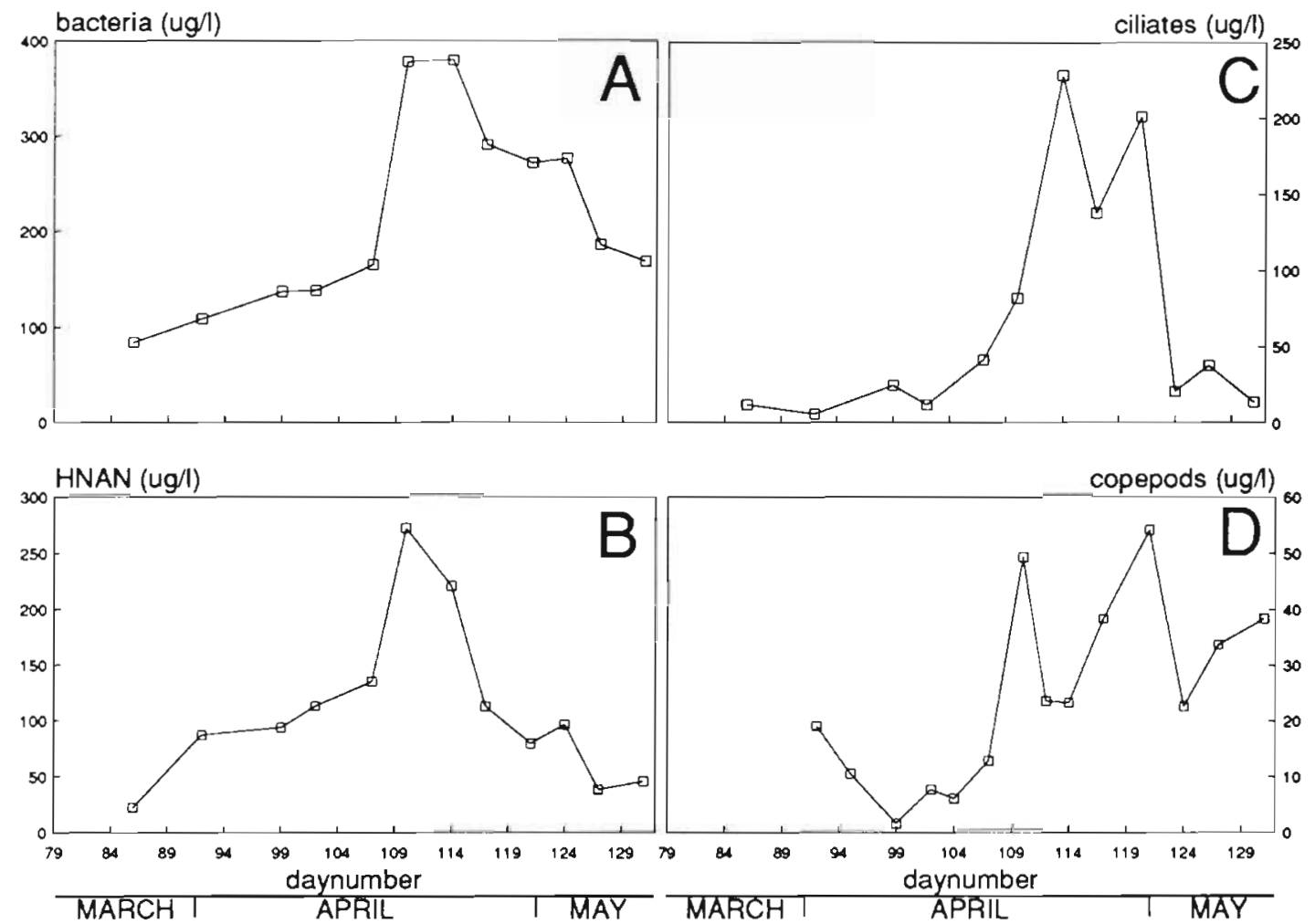

Fig. 5. Time course of biomass of (A) bacteria, (B) heterotrophic nanoflagellates (HNAN), (C) ciliates, and (D) copepods in the Marsdiep water during spring 1990

found by Riegman et al. (1990) during the 1989 Phaeocystis bloom in the Marsdiep. In earlier studies of the spring bloom in Dutch coastal waters Veldhuis et al. (1986, 1987) concluded that Pi was the limiting factor for Phaeocystis. In the Marsdiep Pi concentrations remained relatively high compared with values found in other Dutch coastal waters. This is probably caused by resupply of Pi from sediment suspended in the turbulent Marsdiep water (Froelich 1988) and by input of Pi from Lake IJsselmeer (van Raaphorst \& van der Veer 1990). DOP concentration in the Marsdiep is also high throughout the year (de Jonge \& Postma 1974). Phaeocystis can grow very efficiently using organic phosphates as P-source (van Boekel 1991). The relatively high DOP concentrations found during the bloom may have provided a substantial part of the P-demand of Phaeocystis.

Like the bloom of Phaeocystis colonies, the small bloom of Phaeocystis microflagellates and Asterionella glacialis was followed by an increased lysis rate. It is not clear whether the decline of both dominating algae was caused by lysis alone or that grazing on one or both species was important as a loss factor (see below).

The EA method of measuring lysis as it was used here should be regarded as a semi-quantitative method. It assumes that release of EA in the water can be exclu- sively attributed to phytoplankton. Autolysis of bacteria and nanozooplankton was assumed to be negligible. Also, calculation of particulate EA concentration was based on EA/chl a values derived from cultures of algae. Since the biomass of bacteria and nanozooplankton was small compared to phytoplankton biomass the assumption that autolysis of these heterotrophs was negligible caused only a relative small error in the calculated lysis rate. The extent of the error introduced by taking the EA/chl a value from algal cultures is unknown. The range of values found for different algae (see 'Methods') indicates that in natural populations the EA/chl a value may fluctuate considerably depending on species composition. However, the mean EA/chl a value used for our calculations [12.6 nmol fluorescein $(\mu \mathrm{g} \mathrm{chl} \mathrm{a})^{-1} \mathrm{~h}^{-1}$ ] is close to the value found for Phaeocystis cultures [15.0 nmol fluorescein ( $\mu \mathrm{g} \mathrm{chl} a)^{-1} \mathrm{~h}^{-1}$ ]. During the Phaeocystis dominated part of the spring bloom the calculated lysis rates will probably reflect the condition of the phytoplankton population reasonably well.

\section{Role of bacteria and zooplankton}

The strong increase of bacterio- and protozooplankton biomass over a relatively short period following the 
decline of the Phaeocystis bloom contrasts sharply with the slow increase found during the bloom. This sudden change suggests that the microbial foodweb (bacteriananoflagellates-ciliates) was carbon-limited during the spring bloom. An increased release of dissolved organic carbon (DOC) through lysis during the decline of the Phaeocystis bloom would facilitate the strong increase of biomass in the microbial foodweb. The decrease of bacterial biomass after Day 114 despite the reduced grazing pressure by nanoflagellates also suggests carbon limitation of the bacteria, if nanoflagellates can be considered to be their main predators as is usually found (Riemann et al. 1990, van Duyl et al. 1990). Assuming a linear foodchain from DOC to bacteria to nanoflagellates to ciliates, it appears that the availability of carbon for bacteria (bottom-up control) rather than predation (top-down control) determined the total biomass in the microbial foodchain. Only during the decline of the Phaeocystis bloom (Day 107 to 110) was the bottom-up control released at least. partially. Coupling of phytoplankton and microbial foodchain data suggests the following sequence: Bacteria consumed the organic matter released by the phytoplankton through excretion (until Day 105) and lysis (after Day 105). Bacteria were grazed by nanoflagellates that followed the bacterial development closely. Nanoflagellate biomass development was apparently controlled by ciliate grazing after Day 109. The reappearance of ammonium in the water after Day 114 was probably caused by the excretion of surplus nitrogen by bacteria, nanoflagellates or ciliates (Goldman et al. 1985, Caron et al. 1988). The assumption of a linear foodchain will probably not hold for ciliates, which are able to feed on both nanozooplankton and nanophytoplankton (Riemann et al. 1990 , Weisse \& Scheffel-Möser 1990). Since the peak in ciliate biomass coincided with the bloom of Phaeocystis microflagellates (Figs, 2a \& 5c) it seems likely that ciliates grazed on both autotrophic and heterotrophic nanoplankton during this second bloom period. This is probably the most important short-cut in the foodchain since other groups of organisms that cause nonlinearities, like mixotrophic phyto- and zooplankton or picophytoplankton, are of little importance in the spring bloom situation (Riegman et al. 1990, van Boekel pers. obs.). Hansen \& van Boekel (1991) suggested that ciliates served as major food source for Temora longicornis during the Phaeocystis dominated part of the spring bloom since the copepods clearly were not feeding on phytoplankton. Microzooplankton has been reported before to be an important food source for copepods (Stoecker \& McDowell Capuzzo 1990, Kleppel et al. 1991, Nielsen \& Kiørboe 1991). The decline of ciliate biomass after Day 121 might thus be explained as the combined effect of grazing by copepods and reduced food supply (both nanoflagellates and Phaeocystis microflagellates). In this way copepods can be viewed as the next step following ciliates in the foodchain.

Although little direct evidence was found, the results strongly suggest that the decline of the Phaeocystis spring bloom in the Marsdiep area occurred through cell lysis as a result of nutrient limitation. The data also suggest that bacterio- and zooplankton growth depended largely upon DOC produced through lysis of Phaeocystis.

Acknowledgements. We thank E. Epping for inorganic nitrogen analysis, G. W. Kraay, G. Nieuwland, T. Tahey, and A. A. M. Noordeloos for technical assistance, W. W. C. Gieskes for comments and $T$ Keuning for typing the manuscript. W.v.B. and F.H. were financially supported by the EEC (research project on the Dynamics of Phaeocystis blooms in nutrient enriched coastal zones, Contract no. EV4V-0102-B\{GDF\}\}

\section{LITERATURE CITED}

Admiraal, W., Venekamp, L. A. H. (1986). Significance of tintinnid grazing during blooms of Phaeocystis pouchetif (Haptophyceae) in Dutch coastal waters. Neth. J. Sea Res. 20: $61-66$

Bak, R. P. M., Nieuwland, G. (1991). Patterns in pelagic and benthic nanoflagellate densities in the coastal upwelling system along the Banc d'Arguin, Mauritania. Hydrobiologia (in press)

Beukema, J. J., Cadée, G. C. (1991). Growth rates of the bivalve Macoma baltica in the Wadden Sea during a period of eutrophication: relationships with concentrations of pelagic diatoms and flagellates. Mar. Ecol. Prog. Ser. 68: $249-256$

Bienfang, P. K. (1981). SETCOL - a technologically simple and reliable method for measuring phytoplankton sinking rates. Can. J. Fish. Aquat. Sci. 38: 1289-1294

Borsheim, K. Y., Bratbak, G. (1987). Cell volume to cell carbon conversion factors for a bacterivorous Monas sp. enriched from seawater. Mar. Ecol. Prog. Ser. 36: 171-175

Bratbak, G., Dundas, I. (1984). Bacterial dry matter content and biomass estimations. Appl. environ. Microbiol. 48 : $755-757$

Cadée, G. C., Hegeman, J. (1986). Seasonal and annual variation in Phaeocystis pouchetif (Haptophyceae) in the westernmost inlet of the Wadden Sea during the 1973 to 1985 period. Neth. J. Sea Res. 20: 29-36

Cadée, G. C., Hegeman, J. (1991). Phytoplankton primary production, chlorophyll and species composition, organic carbon and turbidity in the Marsdiep in 1990, compared with foregoing years. Hydrobiol. Bull. 25: 29-35

Caron, D. A., Goldman, J. C., Dennett, M. R. (1988). Experi. mental demonstration of the roles of bacteria and bacterivorous protozoa in plankton nutrient cycles. Hydrobiologia 159: 27-40

Creutzberg, F., Wapenaar, P., Duineveld, G., Lopez, N. (1984). Distribution and density of the benthic fauna in the southern North Sea in relation to bottom characteristics and hydrographic conditions. Rapp. P.-v. Réun. Cons. int. Explor. Mer 183: 101-110 
de Jonge, V. N., Postma, H. (1974). Phosphorus compounds in the Dutch Wadden Sea. Neth. J. Sea Res. 8: 139-153

Dixon, M., Webb, E. C. (1979). Enzymes, 3 edn. Longman, London

Estep, K. W., Nejstgaard, J. Ch., Skjoldal, H. R, Rey, F. (1990). Predation by copepods upon natural populations of Phaeocystis pouchetii as a function of the physiological state of the prey. Mar. Ecol. Prog. Ser. 67: 235-249

Fenchel, T. (1982). Ecology of heterotrophic microflagellates. II. Bioenergetics and growth. Mar. Ecol. Prog. Ser 8: $225-231$

Froelich, P. N. (1988). Kinetic control of dissolved phosphate in natural rivers and estuaries: a primer on the phosphate buffer mechanism. Limnol. Oceanogr. 33: 649-668

Goldman, J. C., Caron, D. A., Anderson, O. K, Dennett, M. R. (1985). Nutrient cycling in a microflagellate foodchain. 1. Nitrogen dynamics. Mar. Ecol. Prog. Ser. 24: 231-242

Hansen, B., Tande, K. S., Berggreen, U. C. (1990). On the trophic fate of Phaeocystis pouchetii (Hariot). III. Functional responses in grazing demonstrated on juvenile stages of Calanus finmarchius (Copepoda) fed diatoms and Phaeocystis. J. Plankton Res. 12: 1173-1187

Hansen, F. C., van Boekel, W. H. M. (1991). Grazing pressure of the calanoid copepod Temora longicornis on a Phaeocystis dominated spring bloom in Dutch coastal waters. Mar. Ecol. Prog. Ser.: 78, 123-129

Hobbie, J. E., Daley, R. J., Jasper, S. (1977). Use of nuclepore filters for counting bacteria by fluorescence microscopy. Appl, environ. Microbiol. 33: 1225-1228

Jenness, M. I., Duineveld, G. C. A. (1985). Effects of tidal currents on chlorophyll a content of sandy sediments in the southern North Sea. Mar. Ecol. Prog. Ser. 21. 283-287

Kleppel, G. S., Holliday, D. V., Pieper, R. E. (1991). Trophic interactions between copepods and microzooplankton: a question about the role of diatoms. Limnol. Oceanogr. 36: $172-178$

Lancelot, C., Billen, G., Sournia, A., Weisse, T., Colijn, F., Veldhuis, M. J. W., Davies, A., Wassman, P. (1987). Phaeocystis blooms and nutrient enrichment in the continental coast zones of the North Sea. Ambio 16: 38-46

Lorenzen, C. J. (1967). Determination of chlorophyll and phaeopigments: spectrofotometric equations. Limnol. Oceanogr. 12: 343-347

Murphy, J., Riley, J. P. (1962). A modified single solution method for the determination of phosphate in natural waters. Anal. Chim. Acta 27: 31-36

Nielsen, T G., Kiørboe, T. (1991). Effects of a storm event on the structure of the pelagic food web with special emphasis on planktonic ciliates. J. Plankton Res. 13: 35-51

Putt, M. Stoecker, D. K. (1989). An experimentally determined carbon: volume ratio for marine 'oligotrichous' ciliates from estuarine and coastal waters. Limnol. Oceanogr 34: $1097-1103$

Riegman, R., Colijn, F., Malschaert, J. F. P., Kloosterhuis, H. T., Cadée, G. C. (1990). Assessment of growth rate limiting

This article was submitted to the editor nutrients in the North Sea by the use of nutrient-uptake kinetics. Neth. J. Sea Res. 26: 53-60

Riemann, B., Sorensen, H. M., Bjørnsen, P. K., Horsted, S. J., Jensen, L. M., Nielsen, T G., Sondergaard, M. (1990). Carbon budgets of the microbial food web in estuarine enclosures. Mar. Ecol. Prog. Ser. 65: 159-170

Stoecker, D. K., McDowell Capuzzo, J. (1990). Predation on Protozoa: its importance to zooplankton. J. Plankton Res. 12: $891-908$

Strickland, J. D. H., Parsons, T R. (1972). A practical handbook of seawater analysis. Bull. Fish. Res. Bd Can. 167: $1-310$

Utermöhl, H. (1958). Zur Vervollkommnung der quantitativen Phytoplankton Methodik. Mitt. int. Verein. theor. angew. Limnol. 9: 1-38

van Boekel, W. H. M. (1991). Ability of Phaeocystis sp. to grow on organic phosphates; direct measurement and prediction with the use of an inhibition constant. J. Plankton Res. 13: $595-570$

van Boekel, W. H. M., Veldhuis, M. J W. (1990). Regulation of alkaline phosphatase synthesis in Phaeocystis sp. Mar Ecol. Prog. Ser. 61: 281-289

van Duyl, F. C., Bak, R. P. M., Kop, A. J., Nieuwland, G. (1990). Bacteria, auto- and heterotrophic nanoflagellates, and their relations in mixed, frontal and stratified waters of the North Sea. Neth. J. Sea Res. 26: 97-109

van Raaphorst, W., van der Veer, H. W. (1990). The phosphorus budget of the Marsdiep tidal basin (Dutch Wadden Sea) in the period 1950-1985: importance of the exchange with the North Sea. Hydrobiologia 195: 21-38

Veldhuis, M. J. W., Colijn, F., Venekamp, L. A. H. (1986). The spring bloom of Phaeocystis pouchetii (Haptophyceae) in Dutch coastal waters. Neth. J. Sea Res. 20: 37-48

Veldhuis, M. J. W., Venekamp, L. A. H., letswaart, T. (1987). Availability of phosphorus sources for blooms of Phaeocystis pouchetii (Haptophyceae) in the North Sea: impact of the river Rhine. Neth. J. Sea Res. 21: 219-229

Verity, P. G., Smayda, T. J. (1989). Nutritional value of Phaeocystis pouchetii (Prymnesiophyceae) and other phytoplankton for Acartia spp. (Copepoda): ingestion, egg production, and growth of nauplii. Mar. Biol. 100: $161-171$

Wassmann, P., Vernet, M., Mitchell, B. G., Rey, F. (1990). Mass sedimentation of Phaeocystis pouchetii in the Barents Sea. Mar. Ecol. Prog. Ser. 66: 183-195

Weisse, T. (1983). Feeding of calanoid copepods in relation to Phaeocystis pouchetii blooms in the German Wadden sea area off Sylt. Mar. Biol. 74: 87-94

Weisse, T., Scheffel-Moser, U. (1990). Growth and grazing loss rates in single-celled Phaeocystis sp. (Prymnesiophyceae). Mar. Biol. 106: 153-158

Zevenboom, W., bij de Vaate, A., Mur, L. C. (1982). Assessment of factors limiting growth rate of Oscillatoria agardhii in hypertrophic Lake Wolderwijd, 1978, by use of physiological indicators. Limnol. Oceanogr. 27: 39-52

Manuscript fIrst received: December 10, 1991

Revised version accepted: March 23, 1992 